\title{
Lung Function In Discharged Patients After Coronavirus Infection (SARS, MERS, COVID-19): A Systemic Review And Meta-Analysis
}

Yan Li Cui ( $\square$ callacui@163.com )

The First Affiliated Hospital of Jinan Unive https://orcid.org/0000-0002-0987-9395

\section{Wen-Wen Cheng}

The First Affiliated Hospital of Jinan Unive

\section{Zhi-Wei Mou}

The First Affiliated Hospital of Jinan Unive

\section{Duan Xiao}

The First Affiliated Hospital of Jinan Unive

Sha-Rui Shan

The First Affiliated Hospital of Guangdong Pharmaceutical University

Zhuo-Ming Chen

The First Affiliated Hospital of Jinan Unive

\section{Research}

Keywords: Lung function, SARS, MERS, COVID-19, follow-up

Posted Date: May 6th, 2021

DOl: https://doi.org/10.21203/rs.3.rs-466024/v1

License: (9) (1) This work is licensed under a Creative Commons Attribution 4.0 International License. Read Full License 


\section{Abstract}

Background: To date, coronaviruses have caused three pandemics. Fewer studies concentrated on the prognosis of lung function.

Objective: To summarize the lung function of the discharged after coronavirus infection.

Methods: We systematically searched PubMed, Cochrane Library, Web of Science, and EMBASE. Two authors independently screened articles and extracted data. On average, predicted values and damage rates of seven lung function indices were pooled by single-arm meta-analysis. And, in severe/critical vs. non-severe/critical and one-year follow-up, they were pooled by two-arm meta-analysis. The source of high heterogeneity was explored by meta-regression or subgroup analysis.

Results: Of the 7798 articles identified, 34 studies were included. On average, the pooled predicted values of the seven indices were within normal except for DLCO $(79.2,95 \% \mathrm{Cl}(76.2 \varangle 82.2))$. Damage of lung function indices accounted for $6.2 \varangle 35.2 \%$ of the discharged with DLCO most, and $83 \otimes 100 \%$ of the damage was mild. Meta-regression showed that different viruses, countries, disease settings, and measurement times were not the source of high heterogeneities. In severe/critical illness vs. nonsevere/critical, predicted values of seven indices were significantly lower (largest gap in DLCO (WMD -11.60, 95\% Cl -14.23 ه-8.98)). However, damage rates got rises only in DLCO (RR 1.74, 95\% Cl 1.46ه2.07) and TLC, having no differences in the other indices. In one-year follow-up, predicted values were significantly improved in the severe/critical subgroup, while having no change in the non-severe/critical subgroup. Damage rates got no improvement in all indices.

Interpretation: A single predicted value or damage rate can't give a clear description of lung function after coronavirus infection, and the trends of the two are sometimes inconsistent. We suggest more prospective cohort or follow-up studies in the future to lessen the influence of differences in lung function measurements across studies.

Registration: PROSPERO (CRD42020192843)

\section{Introduction}

Coronaviruses have caused three pandemics worldwide in the first two decades of the 21 st century (severe acute respiratory syndrome (SARS), middle east respiratory syndrome (MERS), and coronavirus disease 2019 (COVID-19))..$^{1-4}$ COVID-19, which began in December 2019, is still in an emerging, rapidly evolving situation and has caused more than 130 million infections and nearly three million deaths to date. ${ }^{5}$ Furthermore, SARS-CoV-2 (severe acute respiratory syndrome coronavirus 2) has accumulated multiple mutations during its global circulation. ${ }^{6}$ Researches state that COVID-19 may become a sustained epidemic as new flu. ${ }^{1,7}$

During the outbreak of coronaviruses, plenty of articles have sprung up on pathogenesis, epidemiology, clinical features, treatments, and preventions. Studies have shown that the three coronaviruses share many similarities. They are spread through the respiratory tract and mainly cause lung disease. ${ }^{8}$ The most common lung pathology is diffuse alveolar damage with the hyaline membrane, and some also have microvascular thrombosis. ${ }^{9-11}$ Typical imagings are ground-glass opacity, consolidation, reticular pattern, and crazy paving pattern. ${ }^{12,13}$ So, these structural changes may have a similar impact on lung function.

Impaired lung function is generally confirmed to be related to decreased health-related quality of life (HRQL) in COPD, ${ }^{14} \mathrm{ARDS},{ }^{15}$, ${ }^{16}$ SARS, $^{2}$ and COVID-19 studies. ${ }^{17}$ Some studies also reported that damaged forced expiratory volume in 1 second $\left(\mathrm{EFV}_{1}\right){ }^{18}$ forced vital capacity (FVC), or diffusing capacity of the lung for carbon monoxide (DLCO) ${ }^{19}$ is associated with increased mortality. Therefore, lung function is of great importance to the prognosis of patients infected with coronavirus. However, it is still unclear that how coronavirus would affect lung function until now. Because the relevant studies were insufficient ${ }^{4,20}$ and there were distinct differences between them. 2, 4, 17,21-23 The only meta-analysis provided limited information on the prevalences of altered diffusion, restrictive, and obstructive pattern, with a small sample size of COVID-19 patients and a short observation. ${ }^{24}$ 
So, we conducted this systematic review, aiming to systematically describe the prognosis of lung function for the enormous number of patients with coronavirus infection. To our knowledge, it is the first relatively comprehensive meta-analysis on lung function after coronavirus infection (SARS, MERS, COVID-19) with seven indices (FVC, FEV 1 , forced vital capacity/forced expiratory volume in 1 second ( $\left.F E V_{1} / F V C\right)$, total lung capacity $(T L C)$, residual volume (RV), DLCO, diffusion capacity for carbon monoxide per liter of alveolar volume (Kco)). It included the predicted value and damage rate of lung function on average, in severe/critical vs. non-severe/critical, and a one-year follow-up.

\section{Methods}

This systematic review was conducted according to the Preferred Reporting Items for Systematic Reviews and Meta-Analyses guidelines (PRISMA), ${ }^{25}$ and the protocol was registered with PROSPERO (CRD42020192843).

\section{Citation Search and Selection}

The PubMed, EMBASE, Web of Science, and Cochrane Library databases were searched from January 01, 2002, to February 20, 2021, with no publication language limited, using the following search strategy: ("Severe Acute Respiratory Syndrome" OR "SARS" OR "Middle East Respiratory Syndrome" OR "MERS" OR "COVID-19" OR "Coronavirus Disease 2019" OR "2019-nCoV Disease" OR "2019-nCoV Infection" OR "SARS-CoV-2 Disease" OR "SARS-CoV-2 Infection" ) AND ("Respiratory Function Tests" OR "Lung Function Tests" OR "Pulmonary Function Tests" OR "Respiratory Function" OR "Lung Function" OR "Pulmonary Function"). The Medical Subject Headings (MeSH) and all variants were searched. Besides, the reference lists of reviews were manually screened to find all possible articles.

All retrieved articles were independently screened by two authors (YLC, WWC) based on the relevance of the title, abstract, or full text. The full-text articles that met the inclusion and exclusion criteria were included in this review. The inclusion criteria were as follows: (1) original cohort, case-control, case-series, or cross-sectional study; (2) human adults ( $\geq 18$ years) with coronavirus infection and lung function tests (LFTs); (3) follow-up in one year; (4) if an institution published several similar studies, only the one with the largest sample size was included. Studies with the following designs were excluded: (1) reviews, case reports, letters, comments, meeting abstracts, or posters; (2) particular study population with coronavirus infection, such as children, pregnant women, cancer survivors, patients with clinical symptoms, or patients with medicine or rehabilitation training intervention; (3) the sample size of LFTs less than 10. Any disagreement on article inclusion was resolved by an arbitrator (ZMC).

\section{Data Extraction}

Two independent reviewers (DX, ZWM) extracted the data from each included study. The data involved authors, publication year, country, subject characteristics, study design, diagnostic methods of coronavirus infection, seven lung function indices (FVC, $\mathrm{FEV}_{1}, \mathrm{FEV}_{1} / \mathrm{FVC}, \mathrm{TLC}, \mathrm{RV}, \mathrm{DLCO}$, and $\mathrm{Kco}$ ) reported as predicted value or damage rate, and details of follow-up. Most included studies performed LFTs under the American Thoracic Society (ATS) recommendations. ${ }^{26}$ Therefore, the predicted value $>80 \%$ $\left(\mathrm{FEV}_{1} / \mathrm{FVC}>70 \%\right)$ was defined as a normal range, the predicted value in $60 \otimes 80 \%$ was mild damage, in $40 \otimes 60 \%$ was moderate damage, and $<40 \%$ was severe damage. If there were multiple LFTs within one-year follow-up, the lung function measurements of the third month (as the sample mode) after discharge were extracted. The follow-up changes of lung function were determined by the first and last test of LFTs within one year.

\section{Risk of bias assessment}

The risk of bias for the included studies was assessed by two reviewers (YLC, WWC) independently, using the NHLBI's quality assessment tool for observational cohort and cross-sectional studies or the quality assessment tool for Before-After (Pre-Post) studies with no control group. ${ }^{27}$ The criteria which assess the internal validity and risk of bias were evaluated as "Yes", "No", or "Other". The overall rating was defined by the items rated with an affirmative answer: $\geq 75 \%=$ good, $50 \otimes 75 \%=$ fair, $<50 \%=$ poor.

\section{Statistical analysis}


Single-arm meta-analysis was used to pool the estimated predicted values, damage rates, and extent of the damages with $95 \%$ confidence intervals $(\mathrm{Cl})$. Double arcsine transformation was used to stabilize the variance of the extremum for the dichotomous variable. ${ }^{28}$ In the two-arm meta-analysis, weighted mean difference (WMD) and relative risk (RR)/odds ratio (OR) with $95 \% \mathrm{Cl}$ was the effect size of continuous and dichotomous variables, respectively. RR was chosen for the prospective cohort studies. All analyses were performed using Stata MP version 14.0 (Stata Corporation, College Station, TX, USA), with heterogeneities assessed by $\mathrm{I}^{2} .{ }^{29} \mathrm{I}^{2}$ of $25 \%, 50 \%$, and $75 \%$ indicates low, moderate, and high heterogeneity, respectively. When $\mathrm{I}^{2}<50 \%$, the inverse variance weight (fixed-effect model) was used. Inversely, the DerSimonian-Laird procedure (random-effect model) was used. And at the same time, a further meta-regression (number of studies $\geq 10)$ or subgroup analysis $(n<10)$ was performed to explore the source of heterogeneity. Publication bias (studies $\geq 10$ ) was evaluated by Egger's test. ${ }^{30} P<0.05$ was considered as statistical significance.

\section{Results}

The search strategy generated 7798 records. After the exclusion of duplicates, 6820 articles were screened according to the inclusion and exclusion criteria. Then 106 articles were retrieved for full-text review. Finally, 34 articles were included in this study. (Figure 1)

\section{Characteristics of included studies}

Of the 34 included studies (Table 1), 2-4, 17, 20-23, 31-56 8 were on SARS, ${ }^{2,20,21,31-35} 1$ was on MERS, ${ }^{3}$ and 25 were on COVID-19.4, 17, 22, 23, 36-56 A total of 3230 coronavirus-infected patients underwent LFTs, including 905 SARS patients, 73 MERS patients and 2252 COVID-19 patients. Three articles published in Chinese, ${ }^{21,34,35}$ one article published in Spanish, ${ }^{41}$ and all others were in English. The majority of studies were from Asia $(n=18)$ and Europe $(n=14)$, including 16 from China, 2, 4, 21, 23, 32-38, 40, 46, 48, 52,56 one each from Singapore ${ }^{20}$ and South Kore, ${ }^{3}$ and 14 articles from 10 European countries. The other two studies were from Canada. ${ }^{31,43}$ The prospective cohort design ${ }^{2-4,17,23,31,32,36,38,42-45,51-53}$ was most commonly used ( $\left.n=16\right)$, followed by 9 prospective follow-up studies ${ }^{20}, 22,33,37,39,41,49,55,56,4$ retrospective cohort studies ${ }^{40,46-48}, 3$ retrospective follow-up studies ${ }^{21}$, 34,35 , and 2 cross-sectional study studies ${ }^{50,54}$. Twenty-three studies were conducted on the entire hospital setting, 6 were on the severe/critical setting, ${ }^{22,37,44,45,51,55}$ and 5 were on the non-severe/critical setting. ${ }^{17,38,41,49,50} 20$ studies were evaluated as "good" in the quality assessment, and the risk of bias was judged as low. ${ }^{2,3,20-23,31-34,40,41,43,44,46,48,49,51,53,55}$ Another 14 studies had a moderate risk of bias. $4,17,35-39,42,45,47,50,52,54,56$

\section{Predicted values and damage rates of lung function on average}

In total, 23 of the included studies reported the predicted value of lung function, involving seven indices. ${ }^{2,3,17,20-22,31,34,36-39,43-}$ $47,49-53,56$ (Table 2) The overall pooled DLCO \%-predicted $(79.2(95 \% \mathrm{Cl}, 76.2 \varangle 82.2)$ ) of 1428 patients in 19 studies was the lowest and the only one below the normal range. (Figure 2A) The pooled predicted values of the other 6 indices $\left(F V C, F_{1}\right.$,

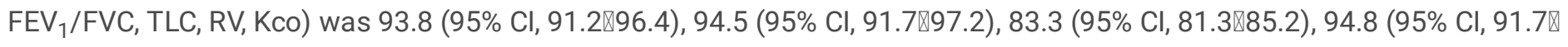
97.9), 97.2 (95\% Cl, 90.7凶103.7), and 90.2 (95\% Cl, 85.4区95.0), respectively. The heterogeneities of the seven indices were high, with $\mathrm{I}^{2}$ ranging from $91.1 \%$ to $94.3 \%$. To explore the source of heterogeneity, we performed meta-regression on the virus, country, disease setting, and measurement time for the seven indices, finding that there were no statistical differences across all the studies. And, publication bias was only found on the FEV $1 / F V C$ index. $(P=0.046)$ (Table 2$)$ Twenty-four studies were included in the meta-analyses to pool the damage rate of lung function in seven indices, ${ }^{2-4}, 17,20,22,23,32-34,36,38-41,43,46,48,51-56$ and the DLCO got the highest rate with $35.2 \%(95 \% \mathrm{Cl}, 28.7 \varangle 41.8 \%)$. (Figure $2 \mathrm{~B})$ The rate of the other six indices varied from $6.2 \%$ to 21.5\%. (Table 2) Similarly, the heterogeneities of the seven indices were high, $\left(I^{2}=79.6 \otimes 96.4 \%\right)$ and no positive findings were found in the meta-regression. However, publication bias was the opposite that it existed in all but DLCO. $(P=0.052)($ Table 2$)$ Several studies also identified the extent of lung function damage, and the mild impairment accounted for most, with the pooled $83 \% \otimes 100 \%$ in FVC, FEV 1 , TLC, DLCO, and Kco. ${ }^{17,20,22,23,33,39,46,56}$ (Table 2) 
A total of 10 cohort studies detailed the predicted values of lung function in two groups of severe/critical and non-severe/critical. (283 vs. 531 patients) $2,3,17,36,38,46,47,51-53$ Differences between the two groups of the seven indices were summarized by metaanalyses. (Table 3) Predicted values in the severe/critical group were found to be worse than that in the non-severe/critical group (all $P<0.013$ ), except for $\mathrm{FEV}_{1} / \mathrm{FVC}$ (no difference between two groups, $P=0.585$ ). And, DLCO got the largest gap, whose lung function in severe/critical decreased -11.6 (WMD, 95\% Cl-14.2ه-9.0) compared with non-severe/critical. ${ }^{2}, 3,17,38,46,47,51-53$ (Figure 3A) All the heterogeneities were acceptable. ( $I^{2}: 0 \unrhd 58.5 \%$ ) (Table 3) Nine cohort studies $4,17,36,38,46,47,51-53$ compared the damage rates of the seven indices between the two groups, two of which were retrospective cohort studies ${ }^{46,47}$ and the others were prospective studies. (483 vs. 492 patients) Meta-analyses found that the risk of lung function damage of DLCO and TLC in the severe/critical group was $1.74(\mathrm{RR}, 95 \% \mathrm{Cl} 1.46 \otimes 2.07)$ (Figure 3B) and $2.00(\mathrm{RR}, 95 \% \mathrm{Cl} 1.38 \otimes 2.90)$ times higher than that in the non-severe/critical group, respectively. $(P=0.000)$ However, there were no significant differences in the other five indices. $(P>$ 0.088) Heterogeneities were low, with $\mathrm{I}^{2}$ varied from 0 to $13.9 \%$. (Table 3 )

\section{Follow-up Changes}

Five articles reported the changes of lung function in predicted value during a one-year follow-up. $2,22,31,37,50$ Meta-analyses showed improvements in FVC, $\mathrm{FEV}_{1} / \mathrm{FVC}$, and $\mathrm{Kco}$. $(P<0.049)$ While there were no statistically significant changes in the other four indices. $(P>0.074)$ (Table 4$)$ Given the high heterogeneity of most indices, we performed subgroup analyses. It showed that all indices got statistically improved in the severe/critical group, $(P<0.049)$ while they had no changes in the non-severe/critical group, except for Kco. $(P>0.208)$ (Supplementary Figure 1) Only three articles covered the damage rate changes of lung function. ${ }^{2}, 22,55$ Analyses showed that there was no statistically significant change in any of the seven indices. $(P>0.182)(T a b l e$ 4) And except that DLCO had a high heterogeneity, $\left(I^{2}=84.6 \%\right)$ no heterogeneity was found in other indices. $\left(I^{2}=0 \%\right)($ Table 4$)$

\section{Discussion}

The predicted value of lung function was the most widely reported in the included studies. They were normal on average (except for DLCO), worse in severe/critical illness, and might get improvements in a one-year follow-up. These trends were consistent with other COVID-19 studies, ${ }^{57-60}$ and even H7N9 ${ }^{61}$ and ARDS studies, ${ }^{16,62,63}$ for sharing a common pathological mechanism mediated by inflammatory factors. ${ }^{64,65}$ But these can't figure out more information about how much the coronaviruses may affect the individual's lung function or the situation of lung function impaired. The reason may be that although studies have corrected continuous lung function according to the local predicting formula, the span of the ATS recommendations for grading respiratory impairment is large. For example, mild respiratory impairment has a range of $60 \otimes 80 \%$ of the predicted values. But in this study, even a difference in the predicted value of less than $10 \%$ was statistically significant. (severe/critical vs. nonsevere/critical; follow-up) Also, this lead to some features of predicted value was quite different from those of damage rate. For example, they got different trends in severe/critical vs. non-severe/critical, and follow-up within one year.

Liking the meta-analysis authored by Torres-Castro $\mathrm{R}^{24}$ many studies reported a rate of respiratory impairment pattern (such as restrictive pattern) with different criteria. ${ }^{35-37,44,46,47,54}$ To minimize the possible errors, we pooled the damage rate of seven indices in detail. On average, the pooled damage rate of FVC (TLC), FEV $1 / F V C$, and DLCO was similar to the percentage of restrictive, obstructive, and diffusing damage patterns reported in that meta-analysis authored by Torres-Castro $\mathrm{R}$, respectively. ${ }^{24}$ DLCO got the highest damage rate. It may be related to the most common abnormal CT patternपinterstitial pneumonia in coronavirus infection ${ }^{13,33}$ or pulmonary fibrosis caused by the activation of fibroblasts during recovery. ${ }^{4,66}$ Damages of seven indices were all mild, and this was consistent with that average predicted values were almost within the normal range. Severe/critical illness was a risk factor for damage only in DLCO and TLC. Several studies on predictors for DLCO damage also proved this, 4, 39, 51, 52 but no studies were conducted on other indices. We suppose they may be more easily affected by age, gender, smoking, or previous lung disease, et al.

Multiple meta-analyses were performed in this paper. Predicted value and damage rate got the highest heterogeneity on average. However, meta-regression showed that the possible sources of heterogeneity (virus, country, disease setting, measurement time) all had no statistical significance. One possibility is that the heterogeneous sources we chose were improper and they had no 
statistical significance. But we preferred that the differences in lung function measurements across studies were so great that they obscured other differences. Cohort and follow-up studies confirmed our assumption that their heterogeneities were low or acceptable. Significant differences were found in predicted value and damage rate in severe/critical vs. non-severe/critical, indicating that different illness settings might be one source of heterogeneity. The meta-analysis by Torres-Castro R mainly pooled the rates of respiratory impairment pattern at discharge or one month after discharge ${ }^{24}$ and they proposed that inflammation during the acute phase may affect results, suggesting a follow-up to 3 months after discharge. ${ }^{67}$ In this review, only predicted values in severe/critical subgroup got significant improvements within one-year follow-up, indicating that different measurement times might not be a source of heterogeneity. But given the small sample size, we consider that more evidence is needed. Therefore, we suggest more prospective cohort or follow-up designs on lung function to increase the credibility and comparability of the results.

There are several limitations in this present review. First, there were fewer studies on SARS, MERS, and follow-up research, although this study had included all relevant literature as much as possible. Second, through comprehensive analysis, we concluded that the greatest source of heterogeneity might be the differences in lung function measurements across studies. But, the differences can't be eliminated, for too many factors and difficult to unify. For example, maybe the effectiveness of predicting formula, 2, 20,32 the criterion of severe illness, 3, 4,37, 40 and the proportion of LFTs over all the discharged patients $2,4,51$, 52 are different across studies. Moreover, various instruments, inspector's skill, patients' cooperation, environmental factors, or psychological factors might affect the LFTs. So we suggest more prospective cohort or follow-up researches. Third, no study provided the lung function condition before infected, and it is unreasonable in fact. So it is impossible to obtain the actual effect of coronavirus infection on lung function. While this review revealed the influences of severe illness and follow-up on lung function under coronavirus infection for the first time, with acceptable heterogeneities. Fourth, we reported the damage rates of seven lung function indices in detail, and one-third of the discharged patients had impaired DLCO. But the percentage of patients who got lung function impairment and the relationship between indices were unknown, for several indices can be injured in one patient. Fifth, for a large number of coronavirus infected, in particular COVID-19, the overall LFTs were laborious, costly, and risky of transmission. ${ }^{68}$ So, it is a challenge to distinguish which and what extent indices were damaged cost-effectively, and it may affect the time for rehabilitation. Researches on the predictors of DLCO damage provided one method, but they were hard to pool for the distinct observation indices involved. $4,39,48,51,52$ We suggest more studies on predictors or prediction models for lung function impairment.

\section{Conclusion}

Three coronaviruses had similar influences on the lung function of infected patients. The predicted value and damage rate of seven lung function indices were consistent on average『damages of lung function indices were mild, with DLCO as the most vulnerable index. However, they had different features in severe/critical vs. non-severe/critical, and follow-up within one year. The dominating source of heterogeneity might be the differences in lung function measurements across studies. Meanwhile, given the previous lung function was unavailable, we suggest more prospective cohort or follow-up designs for further studies.

\section{Abbreviations}

SARS severe acute respiratory syndrome

MERS middle east respiratory syndrome

COVID-19 coronavirus disease 2019

SARS-CoV-2 severe acute respiratory syndrome coronavirus 2

$\mathrm{FEV}_{1}$ forced expiratory volume in 1 second

FVC forced vital capacity 
DLCO diffusing capacity of the lung for carbon monoxide

$\mathrm{FEV}_{1} / \mathrm{FVC}$ forced vital capacity/forced expiratory volume in 1 second

TLC total lung capacity

$\mathrm{RV}$ residual volume

Kco diffusion capacity for carbon monoxide per liter of alveolar volume

LFTs lung function tests

\section{Declarations}

\section{Ethics approval and consent to participate}

Not applicable.

\section{Consent for publication}

Not applicable.

\section{Availability of data and material}

Endnote is used for article screening, and Stata MP version 14.0 (Stata Corporation, College Station, TX, USA) is used for metaanalysis.

\section{Funding support}

This study received salary support from "National Key Research and Development Project"(2020YFC2005700) during the conduct of the study.

\section{Competing interests}

The authors declare that they have no competing interests.

\section{Authors' contributions}

LYC and WWC were responsible for study design, screening, data extraction, data analysis, and writing the article. ZWM and DX helped extract and disposal data. SRS participated in the data analysis and revision of the article. ZMC designed and revised the article.

\section{Acknowledgement}

We are grateful to Jie-ming Shi, who gave us some suggestions in statistical methods.

\section{References}

1. Biswas A, Bhattacharjee U, Chakrabarti AK, et al. Emergence of novel coronavirus and COVID-19: whether to stay or die out? Crit Rev Microbiol. 2020;46(2):182-193.

2. Hui DS, Wong KT, Ko FW, et al. The 1-year impact of severe acute respiratory syndrome on pulmonary function, exercise capacity, and quality of life in a cohort of survivors. Chest. 2005; 128(4):2247-2261.

3. Park WB, Jun KII, Kim G, et al. Correlation between pneumonia severity and pulmonary complications in Middle East Respiratory Syndrome.J Korean Med Sci. 2018;33(24):e169. 
4. Huang CL, Huang LX, Wang YM, et al. 6-month consequences of COVID-19 in patients discharged from hospital: a cohort study.Lancet. 2021;397(10270):220-232.

5. Worldometer COVID-19 Data, Available at https://www.worldometers.info/coronavirus/, [Accessed September 30, 2020].2021-4-6

6. Singh J, Samal J, Kumar V, et al. Structure-function analyses of new SARS-CoV-2 variants B.1.1.7, B.1.351 and B.1.1.28.1: clinical, diagnostic, therapeutic and public health implications. Viruses. 2021;13(3):439.

7. Saad-Roy CM, Wagner CE, Baker RE, et al. Immune life history, vaccination, and the dynamics of SARS-CoV-2 over the next 5 years. Science. 2020;370(6518):811-818.

8. Petrosillo N, Viceconte G, Ergonul O, et al. COVID-19, SARS and MERS: are they closely related? Clin Microbiol Infect. 2020;26(6):729-734.

9. Hwang DM, Chamberlain DW, Poutanen SM, et al. Pulmonary pathology of severe acute respiratory syndrome in Toronto.Mod Pathol. 2005;18(1):1-10.

10. Ackermann M, Verleden SE, Kuehnel M, et al. Pulmonary vascular endothelialitis, thrombosis, and angiogenesis in Covid19.N Engl J Med. 2020;383(2):120-128.

11. Fox SE, Akmatbekov A, Harbert JL, et al. Pulmonary and cardiac pathology in African American patients with COVID-19: an autopsy series from New Orleans.Lancet Respir Med. 2020;8(7):681-686.

12. Wong KT, Antonio GE, Hui DS, et al. Thin-section CT of severe acute respiratory syndrome: evaluation of 73 patients exposed to or with the disease.Radiology. 2003;228(2):395-400.

13. Ye Z, Zhang Y, Wang Y, et al. Chest CT manifestations of new coronavirus disease 2019 (COVID-19): a pictorial review. Eur Radiol. 2020;30(8):4381-4389.

14. Omachi TA, Katz PP, Yelin EH, et al. Depression and health-related quality of life in chronic obstructive pulmonary disease.Am J Med. 2009;122(8):778.e9-15.

15. Schelling G, Stoll C, Vogelmeier C, et al. Pulmonary function and health-related quality of life in a sample of long-term survivors of the acute respiratory distress syndrome.Intensive Care Med. 2000;26(9):1304-11.

16. Herridge MS, Cheung AM, Tansey CM, et al. One-year outcomes in survivors of the acute respiratory distress syndrome. $N$ Engl J Med. 2003;348(8):683-93.

17. van der Brugge S, Talman S, Boonman - de Winter LJM, et al. Pulmonary function and health-related quality of life after COVID-19 pneumonia.Respiratory Medicine. 2021;176:106272.

18. Duong M, Islam S, Rangarajan S, et al. Mortality and cardiovascular and respiratory morbidity in individuals with impaired FEV $_{1}$ (PURE): an international, community-based cohort study.Lancet Glob Health. 2019;7(5):e613-e623.

19. Caron M, Hoa S, Hudson M, et al. Pulmonary function tests as outcomes for systemic sclerosis interstitial lung disease.Eur Respir Rev. 2018;27(148):170102..

20. Ong KC, Ng AWK, Lee LSU, et al. Pulmonary function and exercise capacity in survivors of severe acute respiratory syndrome. European Respiratory Journal. 2004;24(3):436-442.

21. Li L, Sun $X, W u Q$, et al. The lung function status in patients with severe acute respiratory syndrome after ten years of convalescence in Tianjin.Zhonghua jie he he hu xi za zhi. 2015; 38(8):575-578.

22. Fumagalli A, Misuraca $C$, Bianchi $A$, et al. Pulmonary function in patients surviving to COVID-19 pneumonia.Infection. 2021;49(1):153-157.

23. Liang LM, Yang BH, Jiang NC, et al. Three-month follow-up study of survivors of coronavirus disease 2019 after discharge.Journal of Korean Medical Science. 2020;35(47):e418..

24. Torres-Castro R, Vasconcello-Castillo L, Alsina-Restoy X, et al. Respiratory function in patients post-infection by COVID-19: a systematic review and meta-analysis.Pulmonology.2020;S2531-437(20)30245-2.

25. Moher D, Liberati A, Tetzlaff J, Altman DG. Preferred reporting items for systematic reviews and meta-analyses: the PRISMA statement. Ann Intern Med. 2009;151(4):264-269. 
26. Crapo RO, Hankinson JL, Irvin C, et al. Standardization of spirometry, 1994 Update. American Thoracic Society. Am J Respir Crit Care Med. 1995;152:1107-36.

27. National Heart, Lung and Blood Institute. Quality assessment tool for observational cohort and cross-sectional studies. Available from: https://www.nhlbi.nih.gov/health-topics/study-quality-assessment-tools.

28. Freeman MF, Tukey JW. Transformations related to the angular and the square root. Ann Math Stat. 1950;607-611.

29. Higgins JP, Thompson SG, Deeks JJ, Altman DG. Measuring inconsistency in meta-analyses. BMJ. 2003;327(7414):557560.

30. Egger M, Davey Smith G, Schneider M, Minder C. Bias in meta-analysis detected by a simple, graphical test.Bmj. 1997;315(7109):629-634.

31. Tansey CM, Louie M, Loeb M, et al. One-year outcomes and health care utilization in survivors of severe acute respiratory syndrome.Archives of Internal Medicine. 2007;167(12):1312-1320.

32. Ng CK, Chan JWM, Kwan TL, et al. Six month radiological and physiological outcomes in severe acute respiratory syndrome (SARS) survivors. Thorax. 2004;59(10):889-891.

33. Xie LX, Liu YN, Xiao YY, et al. Follow-up study on pulmonary function and lung radiographic changes in rehabilitating severe acute respiratory syndrome patients after discharge.Chest. 2005;127(6):2119-2124.

34. Liu T, Peng M, Cai BQ, et al. Assessment of health-related quality of life in cured SARS patients.Zhongguo Yi Xue Ke Xue Yuan Xue Bao. 2003;25(5):516-519.

35. He ZY, Liu Y, Xing J, et al. A follow-up study of the lung function and the chest CT changes in medical staff with severe acute respiratory syndrome in Beijing.Zhonghua jie he he hu xi za zhi. 2005;28(1):10-12.

36. You JJ, Zhang L, Ni-jia-Ti M, et al. Anormal pulmonary function and residual CT abnormalities in rehabilitating COVID-19 patients after discharge. Journal of Infection. 2020;81(2):e150-152.

37. Li XY, Wang CS, Kou SJ, et al. Lung ventilation function characteristics of survivors from severe COVID-19: a prospective study. Critical Care. 2020;24(1)300.

38. Mo XN, Jian WH, Su ZQ, et al. Abnormal pulmonary function in COVID-19 patients at time of hospital discharge.European Respiratory Journal. 2020;55(6):2001217..

39. Bellan M, Soddu D, Balbo PE, et al. Respiratory and psychophysical sequelae among patients with covid-19 four months after hospital discharge.JAMA Network Open. 2021;4(1):e2036142.

40. Lv DQ, Chen X, Wang XD, et al. Pulmonary function of patients with 2019 novel coronavirus induced-pneumonia: a retrospective cohort study.Annals of Palliative Medicine. 2020;9(5):3447-3452.

41. Tabernero Huguet E, Urrutia Gajarte A, Ruiz Iturriaga LA, et al. Pulmonary function in early follow-up of patients with COVID19 pneumonia.Archivos de Bronconeumologia. 2021;57:75-76.

42. Guler SA, Ebner L, Beigelman C, et al. Pulmonary function and radiological features four months after COVID-19: first results from the national prospective observational Swiss COVID-19 lung study. The European respiratory journal. 2021;2003690.

43. Shah AS, Wong AW, Hague CJ, et al. A prospective study of 12-week respiratory outcomes in COVID-19-related hospitalisations. Thorax. 2020;216308.

44. Truffaut L, Demey L, Bruyneel AV, et al. Post-discharge critical COVID-19 lung function related to severity of radiologic lung involvement at admission. Respir Res. 2021;22(1):29.

45. Anastasio F, Barbuto S, Scarnecchia E, et al. Medium-term impact of COVID-19 on pulmonary function, functional capacity and quality of life.Eur Respir J. 2021;2004015.

46. Huang Y, Tan C, Wu J, et al. Impact of coronavirus disease 2019 on pulmonary function in early convalescence phase.Respiratory Research. 2020;21(1):163.

47. Frija-Masson J, Debray MP, Gilbert M, et al. Functional characteristics of patients with SARS-CoV-2 pneumonia at 30 days post-infection. European Respiratory Journal. 2020;56(2):2001754.

48. Zhao YM, Shang YM, Song WB, et al. Follow-up study of the pulmonary function and related physiological characteristics of COVID-19 survivors three months after recovery.EClinicalMedicine. 2020;25:100463. 
49. Daher A, Balfanz P, Cornelissen C, et al. Follow up of patients with severe coronavirus disease 2019 (COVID-19): pulmonary and extrapulmonary disease sequelae. Respiratory Medicine. 2020;174:106197.

50. Bonnesen B, Toennesen LL, Rasmussen KB, et al. Early improvements in pulmonary function after severe COVID-19 requiring mechanical ventilation. Infectious Diseases. 2020;53(3):218-221.

51. Lerum TV, Aaløkken TM, Brønstad E, et al. Dyspnoea, lung function and CT findings three months after hospital admission for COVID-19. The European respiratory journal. 2020;2003448.

52. Qin W, Chen S, Zhang Y, et al. Diffusion capacity abnormalities for carbon monoxide in patients with COVID-19 at Threemonth follow-up. J Med Syst. 2021;2003677.

53. Osman M, Berman M, van den Borst B, et al. Comprehensive health assessment three months after recovery from acute COVID-19. Eur Heart J Case Rep. 2020;ciaa1750.

54. Smet J, Stylemans D, Hanon S, et al. Clinical status and lung function 10 weeks after severe SARS-CoV-2 infection.Respiratory Medicine. 2021;176:106276.

55. Sonnweber T, Sahanic S, Pizzini A, et al. Cardiopulmonary recovery after COVID-19 - an observational prospective multicenter trial. The European respiratory journal. 2020;2003481.

56. Gao Y, Chen R, Geng Q, et al. Cardiopulmonary exercise testing might be helpful for interpretation of impaired pulmonary function in recovered COVID-19 patients. The European respiratory journal. 2021;57(1):2004265.

57. Chiang $\mathrm{CH}$, Shih JF, Su WJ, et al. Eight-month prospective study of 14 patients with hospital-acquired severe acute respiratory syndrome. Mayo Clinic Proceedings. 2004;79(11):1372-1379.

58. Hsu HH, Tzao C, Wu CP, et al. Correlation of high-resolution $\mathrm{CT}$, symptoms, and pulmonary function in patients during recovery from severe acute respiratory syndrome. Chest. 2004; 126(1):149-158.

59. Zhang $\mathrm{P}, \mathrm{Li} \mathrm{J}$, Liu H, et al. Long-term bone and lung consequences associated with hospital-acquired severe acute respiratory syndrome: a 15-year follow-up from a prospective cohort study.Bone Research. 2020;8(1)8.

60. Su MC, Hsieh YT, Wang YH, et al. Exercise capacity and pulmonary function in hospital workers recovered from severe acute respiratory syndrome. Respiration. 2007;74(5):511-516.

61. Chen J, Wu J, Hao S, et al. Long term outcomes in survivors of epidemic Influenza A (H7N9) virus infection.Sci Rep. 2017;7(1):17275.

62. Orme JJr, Romney JS, Hopkins RO, et al. Pulmonary function and health-related quality of life in survivors of acute respiratory distress syndrome.Am J Respir Crit Care Med. 2003;167(5):690-694.

63. Hsieh MJ, Lee WC, Cho HY, et al. Recovery of pulmonary functions, exercise capacity, and quality of life after pulmonary rehabilitation in survivors of ARDS due to severe influenza A (H1N1) pneumonitis. Influenza Other Respir Viruses. 2018;12(5):643-648.

64. Ruuskanen O, Lahti E, Jennings LC, et al. Viral pneumonia.Lancet. 2011;377(9773):1264-1275.

65. Xu Z, Shi L, Wang Y, et al. Pathological findings of COVID-19 associated with acute respiratory distress syndrome.Lancet Respir Med. 2020;8(4):420-422.

66. Boyd DF, Allen EK, Randolph AG, et al. Exuberant fibroblast activity compromises lung function via ADAMTS4.Nature. 2020;587(7834):466-471.

67. British Thoracic Society. British thoracic society guidance on respiratory follow up of patients with a clinic radiological diagnosis of COVID-19 pneumonia [Internet]. Available from:https://www.brit-thoracic.org.uk/document-library/qualityimprovement/covid-19/resp-followup-guidance-post-covid-pneumonia/.

68. Kouri A, Gupta S, Yadollahi A, et al. Addressing reduced laboratory-based pulmonary function testing during a pandemic. Chest. 2020;158(6):2502-2510.

\section{Tables}


Table 1

Characteristics of the included studies

\begin{tabular}{|c|c|c|c|c|c|c|c|c|c|}
\hline $\begin{array}{l}\text { Author, } \\
\text { Year }\end{array}$ & $\begin{array}{l}\text { Region, } \\
\text { Country }\end{array}$ & $\begin{array}{l}\text { Virus, } \\
\text { Diagnosis } \\
\text { method }\end{array}$ & $\begin{array}{l}\text { Study } \\
\text { Design }\end{array}$ & $\begin{array}{l}\mathbf{N}_{\text {virus-infected }} \\
\text { a }\end{array}$ & $\begin{array}{l}N_{\text {LFT }} \\
s^{b}\end{array}$ & $\begin{array}{l}\text { Age, } \\
\text { years, } \\
\text { Mean } \\
(\mathrm{SD})\end{array}$ & $\begin{array}{l}\text { Male } \\
\text { Sex, } \\
(\%)\end{array}$ & $\begin{array}{l}\text { Follow-up } \\
\text { times, } \\
\text { months } \\
\text { (mo), } \\
\text { years }\end{array}$ & $\begin{array}{l}\text { Quality } \\
\text { c }\end{array}$ \\
\hline $\begin{array}{l}\text { Hui DS, } \\
2005[2]\end{array}$ & $\begin{array}{l}\text { Hongkong, } \\
\text { China }\end{array}$ & $\begin{array}{l}\text { SARS- } \\
\text { Cov, } \\
\text { laboratory } \\
+\end{array}$ & $\begin{array}{l}\text { prospective } \\
\text { cohort }\end{array}$ & $\begin{array}{l}123 \\
\text { discharged }\end{array}$ & 97 & $\begin{array}{l}36.9 \\
(9.5)\end{array}$ & $\begin{array}{l}39 \\
(40.2 \%)\end{array}$ & $\begin{array}{l}3,6,12 \\
\text { mo }\end{array}$ & good \\
\hline $\begin{array}{l}\text { Ong KC, } \\
2005[20]\end{array}$ & Singapore & $\begin{array}{l}\text { SARS- } \\
\text { Cov, } \\
\text { laboratory } \\
+\end{array}$ & $\begin{array}{l}\text { prospective } \\
\text { follow-up }\end{array}$ & $\begin{array}{l}151 \\
\text { discharged }\end{array}$ & 94 & $\begin{array}{l}37 \\
(12)\end{array}$ & $\begin{array}{l}24 \\
(26 \%)\end{array}$ & $12 \mathrm{mo}$ & good \\
\hline $\begin{array}{l}\text { Li L, } \\
\text { 2015[21] }\end{array}$ & $\begin{array}{l}\text { TianJin, } \\
\text { China }\end{array}$ & $\begin{array}{l}\text { SARS- } \\
\text { Cov, } \\
\text { clinical/ } \\
\text { laboratory } \\
+\end{array}$ & $\begin{array}{l}\text { retrospective } \\
\text { follow-up }\end{array}$ & $\begin{array}{l}25 \\
\text { discharged }\end{array}$ & 25 & $\begin{array}{l}42.3 \\
(11.9)\end{array}$ & $6(24 \%)$ & $\begin{array}{l}\text { discharge, } \\
10 \text { years }\end{array}$ & good \\
\hline $\begin{array}{l}\text { Tansey } \\
\text { CM, } \\
2007[31]\end{array}$ & Canada & $\begin{array}{l}\text { SARS- } \\
\text { Cov, } \\
\text { laboratory } \\
+\end{array}$ & $\begin{array}{l}\text { prospective } \\
\text { cohort }\end{array}$ & $\begin{array}{l}198 \\
\text { discharged }\end{array}$ & 103 & $\begin{array}{l}42 \\
(13.5)\end{array}$ & $\begin{array}{l}39 \\
(33.3 \%)\end{array}$ & $\begin{array}{l}3,6,12 \\
\text { mo }\end{array}$ & good \\
\hline $\begin{array}{l}\mathrm{Ng} \mathrm{CK}, \\
2004[32]\end{array}$ & $\begin{array}{l}\text { Hongkong, } \\
\text { China }\end{array}$ & $\begin{array}{l}\text { SARS- } \\
\text { Cov, } \\
\text { laboratory } \\
+\end{array}$ & $\begin{array}{l}\text { prospective } \\
\text { cohort }\end{array}$ & $\begin{array}{l}93 \\
\text { discharged }\end{array}$ & 57 & $\begin{array}{l}38.1 \\
(10.7)\end{array}$ & $\begin{array}{l}22 \\
(38.6 \%)\end{array}$ & $6 \mathrm{mo}$ & good \\
\hline $\begin{array}{l}\text { Xie LX, } \\
\text { 2005[33] }\end{array}$ & $\begin{array}{l}\text { Beijing, } \\
\text { China }\end{array}$ & $\begin{array}{l}\text { SARS- } \\
\text { Cov, } \\
\text { laboratory } \\
+\end{array}$ & $\begin{array}{l}\text { prospective } \\
\text { follow-up }\end{array}$ & $\begin{array}{l}208 \\
\text { discharged }\end{array}$ & 51 & - & - & $3 \mathrm{mo}$ & good \\
\hline $\begin{array}{l}\text { Liu T, } \\
2003[34]\end{array}$ & $\begin{array}{l}\text { Beijing, } \\
\text { China }\end{array}$ & $\begin{array}{l}\text { SARS- } \\
\text { Cov, } \\
\text { clinical/ } \\
\text { laboratory } \\
+\end{array}$ & $\begin{array}{l}\text { retrospective } \\
\text { follow-up }\end{array}$ & $\begin{array}{l}119 \\
\text { discharged }\end{array}$ & 72 & - & - & $1 \mathrm{mo}$ & good \\
\hline $\begin{array}{l}\mathrm{He} Z Y_{1} \\
2005[35]\end{array}$ & $\begin{array}{l}\text { Beijing, } \\
\text { China }\end{array}$ & $\begin{array}{l}\text { SARS- } \\
\text { Cov, - }\end{array}$ & $\begin{array}{l}\text { retrospective } \\
\text { follow-up }\end{array}$ & $\begin{array}{l}456 \\
\text { discharged }\end{array}$ & 406 & $33(9)$ & - & $6 \mathrm{mo}$ & fair \\
\hline $\begin{array}{l}\text { Park WB, } \\
2018[3]\end{array}$ & Korea & $\begin{array}{l}\text { MERS- } \\
\text { Cov, } \\
\text { laboratory } \\
+\end{array}$ & $\begin{array}{l}\text { prospective } \\
\text { cohort }\end{array}$ & $\begin{array}{l}146 \\
\text { discharged }\end{array}$ & 73 & $\begin{array}{l}51.2 \\
(1 \\
1.5)\end{array}$ & $\begin{array}{l}43 \\
(58.9 \%)\end{array}$ & 1 year & good \\
\hline $\begin{array}{l}\text { Huang CL, } \\
\text { 2021[4] }\end{array}$ & $\begin{array}{l}\text { Wuhan, } \\
\text { China }\end{array}$ & $\begin{array}{l}2019- \\
\text { nCoV, } \\
\text { laboratory } \\
+\end{array}$ & $\begin{array}{l}\text { prospective } \\
\text { cohort }\end{array}$ & $\begin{array}{l}2436 \\
\text { discharged }\end{array}$ & 349 & - & - & $6 \mathrm{mo}$ & fair \\
\hline $\begin{array}{l}\text { van der S, } \\
2021[17]\end{array}$ & $\begin{array}{l}\text { Breda, the } \\
\text { Netherlands }\end{array}$ & $\begin{array}{l}2019- \\
\text { nCoV, } \\
\text { laboratory } \\
+\end{array}$ & $\begin{array}{l}\text { prospective } \\
\text { cohort }\end{array}$ & $\begin{array}{l}\text { - non- } \\
\text { critical }\end{array}$ & 101 & $\begin{array}{l}66.4 \\
(12.6)\end{array}$ & $\begin{array}{l}58 \\
(57.4 \%)\end{array}$ & $1.5 \mathrm{mo}$ & fair \\
\hline $\begin{array}{l}\text { Fumagalli } \\
\text { A, 2021[22] }\end{array}$ & $\begin{array}{l}\text { Lombardy, } \\
\text { Italy }\end{array}$ & $\begin{array}{l}2019- \\
\text { nCoV, } \\
\text { laboratory } \\
+\end{array}$ & $\begin{array}{l}\text { prospective } \\
\text { follow-up }\end{array}$ & 13 ICU & 13 & $\begin{array}{l}57.8 \\
(10.0)\end{array}$ & $\begin{array}{l}12 \\
(92.3 \%)\end{array}$ & $\begin{array}{l}\text { discharge, } \\
1.5 \mathrm{mo}\end{array}$ & good \\
\hline
\end{tabular}




\begin{tabular}{|c|c|c|c|c|c|c|c|c|c|}
\hline $\begin{array}{l}\text { Author, } \\
\text { Year }\end{array}$ & $\begin{array}{l}\text { Region, } \\
\text { Country }\end{array}$ & $\begin{array}{l}\text { Virus, } \\
\text { Diagnosis } \\
\text { method }\end{array}$ & $\begin{array}{l}\text { Study } \\
\text { Design }\end{array}$ & $\begin{array}{l}\mathbf{N}_{\text {virus-infected }} \\
\text { a }\end{array}$ & $\begin{array}{l}N_{\text {LFT }} \\
s^{b}\end{array}$ & $\begin{array}{l}\text { Age, } \\
\text { years, } \\
\text { Mean } \\
(S D)\end{array}$ & $\begin{array}{l}\text { Male } \\
\text { Sex, } \\
(\%)\end{array}$ & $\begin{array}{l}\text { Follow-up } \\
\text { times, } \\
\text { months } \\
\text { (mo), } \\
\text { years }\end{array}$ & $\begin{array}{l}\text { Quality } \\
\text { c }\end{array}$ \\
\hline $\begin{array}{l}\text { Liang LM, } \\
\text { 2020[23] }\end{array}$ & $\begin{array}{l}\text { Wuhan, } \\
\text { China }\end{array}$ & $\begin{array}{l}2019- \\
\text { nCoV, } \\
\text { laboratory } \\
+\end{array}$ & $\begin{array}{l}\text { prospective } \\
\text { cohort }\end{array}$ & $\begin{array}{l}134 \\
\text { discharged }\end{array}$ & 76 & $\begin{array}{l}41.3 \\
(13.8)\end{array}$ & $\begin{array}{l}21 \\
(27.6 \%)\end{array}$ & $3 \mathrm{mo}$ & good \\
\hline $\begin{array}{l}\text { You JJ, } \\
2020[36]\end{array}$ & $\begin{array}{l}\text { Hubei, } \\
\text { China }\end{array}$ & $\begin{array}{l}2019- \\
\text { nCoV, } \\
\text { laboratory } \\
+\end{array}$ & $\begin{array}{l}\text { prospective } \\
\text { cohort }\end{array}$ & - & 18 & $\begin{array}{l}10 \\
(55.6)\end{array}$ & $\begin{array}{l}50.7 \\
(12.1 \%)\end{array}$ & $1 \mathrm{mo}$ & fair \\
\hline $\begin{array}{l}\text { Li XY, } \\
2020[37]\end{array}$ & $\begin{array}{l}\text { Haerbin, } \\
\text { China }\end{array}$ & $\begin{array}{l}\text { 2019- } \\
\text { nCoV, - }\end{array}$ & $\begin{array}{l}\text { prospective } \\
\text { follow-up }\end{array}$ & - severe & 18 & - & - & $0.5,1 \mathrm{mo}$ & fair \\
\hline $\begin{array}{l}\text { Mo XN, } \\
2020[38]\end{array}$ & $\begin{array}{l}\text { Guangzhou, } \\
\text { China }\end{array}$ & $\begin{array}{l}2019- \\
\text { nCoV, } \\
\text { laboratory } \\
+\end{array}$ & $\begin{array}{l}\text { prospective } \\
\text { cohort }\end{array}$ & $\begin{array}{l}\text { - non- } \\
\text { critical }\end{array}$ & 110 & $\begin{array}{l}49.1 \\
(14.0)\end{array}$ & $\begin{array}{l}55 \\
(50 \%)\end{array}$ & discharge & fair \\
\hline $\begin{array}{l}\text { Bellan M, } \\
2021[39]\end{array}$ & $\begin{array}{l}\text { Novara, } \\
\text { Italy }\end{array}$ & $\begin{array}{l}2019- \\
\text { nCoV, } \\
\text { laboratory } \\
+\end{array}$ & $\begin{array}{l}\text { prospective } \\
\text { follow-up }\end{array}$ & $\begin{array}{l}732 \\
\text { discharged }\end{array}$ & 224 & $\begin{array}{l}60.6 \\
(15.7)\end{array}$ & $\begin{array}{l}142 \\
(59.7 \%)\end{array}$ & $4 \mathrm{mo}$ & fair \\
\hline $\begin{array}{l}\text { Lv DQ, } \\
2020[40]\end{array}$ & $\begin{array}{l}\text { Taizhou, } \\
\text { China }\end{array}$ & $\begin{array}{l}2019- \\
\text { nCoV, } \\
\text { laboratory } \\
+\end{array}$ & $\begin{array}{l}\text { retrospective } \\
\text { cohort }\end{array}$ & $\begin{array}{l}137 \\
\text { discharged }\end{array}$ & 137 & $\begin{array}{l}47 \\
(13)\end{array}$ & $\begin{array}{l}71 \\
(51.8 \%)\end{array}$ & $\begin{array}{l}\text { discharge, } \\
0.5 \mathrm{mo}\end{array}$ & good \\
\hline $\begin{array}{l}\text { Tabernero } \\
\mathrm{HE} \text {, } \\
2021[41]\end{array}$ & Spain & $\begin{array}{l}2019- \\
\text { nCoV, } \\
\text { laboratory } \\
+\end{array}$ & $\begin{array}{l}\text { prospective } \\
\text { follow-up }\end{array}$ & $\begin{array}{l}128 \text { non- } \\
\text { critial }\end{array}$ & 104 & $\begin{array}{l}58.1 \\
(12.9)\end{array}$ & $\begin{array}{l}54 \\
(51.9 \%)\end{array}$ & $1-1.5 \mathrm{mo}$ & good \\
\hline $\begin{array}{l}\text { Guler SA, } \\
\text { 2021[42] }\end{array}$ & Swiss & $\begin{array}{l}\text { 2019- } \\
\text { nCoV, - }\end{array}$ & $\begin{array}{l}\text { prospective } \\
\text { cohort }\end{array}$ & - & 72 & - & - & $4 \mathrm{mo}$ & fair \\
\hline $\begin{array}{l}\text { Shah AS, } \\
\text { 2020[43] }\end{array}$ & Canada & $\begin{array}{l}2019- \\
\text { nCoV, } \\
\text { laboratory } \\
+\end{array}$ & $\begin{array}{l}\text { prospective } \\
\text { cohort }\end{array}$ & $\begin{array}{l}82 \\
\text { discharged }\end{array}$ & 57 & $\begin{array}{l}64.9 \\
(15.2)\end{array}$ & $\begin{array}{l}41 \\
(68 \%)\end{array}$ & $3 \mathrm{mo}$ & good \\
\hline $\begin{array}{l}\text { Truffaut L, } \\
2021[44]\end{array}$ & $\begin{array}{l}\text { Brussels, } \\
\text { Belgium }\end{array}$ & $\begin{array}{l}2019- \\
\text { nCoV, } \\
\text { clinical/ } \\
\text { laboratory } \\
+\end{array}$ & $\begin{array}{l}\text { prospective } \\
\text { cohort }\end{array}$ & 33 ICU & 22 & $\begin{array}{l}54.6 \\
(10.9)\end{array}$ & $\begin{array}{l}16 \\
(72.7 \%)\end{array}$ & $3 \mathrm{mo}$ & good \\
\hline $\begin{array}{l}\text { Anastasio } \\
\text { F, 2021[45] }\end{array}$ & $\begin{array}{l}\text { Sondalo, } \\
\text { Italy }\end{array}$ & $\begin{array}{l}2019- \\
\text { nCoV, } \\
\text { laboratory } \\
+\end{array}$ & $\begin{array}{l}\text { prospective } \\
\text { cohort }\end{array}$ & 61 ARDS & 61 & $\begin{array}{l}65.6 \\
(11.4)\end{array}$ & $\begin{array}{l}54 \\
(83.1 \%)\end{array}$ & $4 \mathrm{mo}$ & fair \\
\hline $\begin{array}{l}\text { Huang Y, } \\
2020[46]\end{array}$ & $\begin{array}{l}\text { Zhuhai, } \\
\text { China }\end{array}$ & $\begin{array}{l}2019- \\
\text { nCoV, } \\
\text { laboratory } \\
+\end{array}$ & $\begin{array}{l}\text { retrospective } \\
\text { cohort }\end{array}$ & $\begin{array}{l}70 \\
\text { discharged }\end{array}$ & 57 & $\begin{array}{l}46.7 \\
(13.8)\end{array}$ & $\begin{array}{l}26 \\
(45.6 \%)\end{array}$ & $1 \mathrm{mo}$ & good \\
\hline $\begin{array}{l}\text { Frija- } \\
\text { Masson J, } \\
\text { 2020[47] }\end{array}$ & $\begin{array}{l}\text { Paris, } \\
\text { France }\end{array}$ & $\begin{array}{l}2019- \\
\text { nCoV, } \\
\text { laboratory } \\
+\end{array}$ & $\begin{array}{l}\text { retrospective } \\
\text { cohort }\end{array}$ & - & 50 & $\begin{array}{l}54 \\
(12.2)\end{array}$ & $\begin{array}{l}28 \\
(56 \%)\end{array}$ & $1 \mathrm{mo}$ & fair \\
\hline
\end{tabular}




\begin{tabular}{|c|c|c|c|c|c|c|c|c|c|}
\hline $\begin{array}{l}\text { Author, } \\
\text { Year }\end{array}$ & $\begin{array}{l}\text { Region, } \\
\text { Country }\end{array}$ & $\begin{array}{l}\text { Virus, } \\
\text { Diagnosis } \\
\text { method }\end{array}$ & $\begin{array}{l}\text { Study } \\
\text { Design }\end{array}$ & $\begin{array}{l}\mathbf{N}_{\text {virus-infected }} \\
\text { a }\end{array}$ & $\begin{array}{l}N_{\text {LFT }} \\
s^{b}\end{array}$ & $\begin{array}{l}\text { Age, } \\
\text { years, } \\
\text { Mean } \\
\text { (SD) }\end{array}$ & $\begin{array}{l}\text { Male } \\
\text { Sex, } \\
(\%)\end{array}$ & $\begin{array}{l}\text { Follow-up } \\
\text { times, } \\
\text { months } \\
\text { (mo), } \\
\text { years }\end{array}$ & $\begin{array}{l}\text { Quality } \\
\text { c }\end{array}$ \\
\hline $\begin{array}{l}\text { Zhao YM, } \\
\text { 2020[48] }\end{array}$ & $\begin{array}{l}\text { Zhengzhou, } \\
\text { China }\end{array}$ & $\begin{array}{l}2019- \\
\text { nCoV, } \\
\text { laboratory } \\
+\end{array}$ & $\begin{array}{l}\text { retrospective } \\
\text { cohort }\end{array}$ & $\begin{array}{l}74 \text { non- } \\
\text { critical }\end{array}$ & 55 & $\begin{array}{l}47.7 \\
(15.5)\end{array}$ & $\begin{array}{l}32 \\
(58.2 \%)\end{array}$ & $3 \mathrm{mo}$ & good \\
\hline $\begin{array}{l}\text { Daher A, } \\
2020[49]\end{array}$ & $\begin{array}{l}\text { Aachen, } \\
\text { Germany }\end{array}$ & $\begin{array}{l}2019- \\
\text { nCoV, } \\
\text { laboratory } \\
+\end{array}$ & $\begin{array}{l}\text { prospective } \\
\text { follow-up }\end{array}$ & $\begin{array}{l}33 \text { non- } \\
\text { critical }\end{array}$ & 33 & $64(3)$ & $\begin{array}{l}22 \\
(66.7 \%)\end{array}$ & $1.5 \mathrm{mo}$ & good \\
\hline $\begin{array}{l}\text { Bonnesen } \\
\text { B, 2020[50] }\end{array}$ & $\begin{array}{l}\text { Roskilde, } \\
\text { Denmark }\end{array}$ & $\begin{array}{l}2019- \\
\text { nCoV, } \\
\text { laboratory } \\
+\end{array}$ & $\begin{array}{l}\text { cross- } \\
\text { sectional }\end{array}$ & 16 critical & 12 & $\begin{array}{l}62 \\
(8.4)\end{array}$ & $\begin{array}{l}11 \\
(91.7 \%)\end{array}$ & 1, $3 \mathrm{mo}$ & fair \\
\hline $\begin{array}{l}\text { Lerum TV, } \\
2020[51]\end{array}$ & Norway & $\begin{array}{l}2019- \\
\text { nCoV, } \\
\text { laboratory } \\
+\end{array}$ & $\begin{array}{l}\text { prospective } \\
\text { cohort }\end{array}$ & $\begin{array}{l}103 \\
\text { discharged }\end{array}$ & 103 & $\begin{array}{l}60.1 \\
(17.3)\end{array}$ & $\begin{array}{l}54 \\
(52 \%)\end{array}$ & $1.5,3 \mathrm{mo}$ & good \\
\hline $\begin{array}{l}\text { Qin W, } \\
\text { 2021[52] }\end{array}$ & $\begin{array}{l}\text { Wuhan, } \\
\text { China }\end{array}$ & $\begin{array}{l}2019- \\
\text { nCoV, } \\
\text { clinical/ } \\
\text { laboratory } \\
+\end{array}$ & $\begin{array}{l}\text { prospective } \\
\text { cohort }\end{array}$ & $\begin{array}{l}668 \\
\text { discharged }\end{array}$ & 81 & $\begin{array}{l}59 \\
(14)\end{array}$ & $\begin{array}{l}34 \\
(42 \%)\end{array}$ & $3 \mathrm{mo}$ & fair \\
\hline $\begin{array}{l}\text { Osman M, } \\
\text { 2020[53] }\end{array}$ & $\begin{array}{l}\text { Nijmegen, } \\
\text { the } \\
\text { Netherlands }\end{array}$ & $\begin{array}{l}2019- \\
\text { nCoV, } \\
\text { clinical/ } \\
\text { laboratory } \\
+\end{array}$ & $\begin{array}{l}\text { prospective } \\
\text { cohort }\end{array}$ & $\begin{array}{l}170 \\
\text { discharged }\end{array}$ & 124 & $\begin{array}{l}59 \\
(14)\end{array}$ & $\begin{array}{l}74 \\
(60 \%)\end{array}$ & $3 \mathrm{mo}$ & good \\
\hline $\begin{array}{l}\text { Smet J, } \\
2021[54]\end{array}$ & $\begin{array}{l}\text { Brussels, } \\
\text { Belgium }\end{array}$ & $\begin{array}{l}\text { 2019- } \\
\text { nCoV, - }\end{array}$ & $\begin{array}{l}\text { cross- } \\
\text { sectional }\end{array}$ & - & 220 & $\begin{array}{l}53 \\
(13)\end{array}$ & $\begin{array}{l}136 \\
(62 \%)\end{array}$ & $2.5 \mathrm{mo}$ & fair \\
\hline $\begin{array}{l}\text { Sonnweber } \\
\text { T, 2020[55] }\end{array}$ & $\begin{array}{l}\text { Innsbruck, } \\
\text { Austria }\end{array}$ & $\begin{array}{l}2019- \\
\text { nCoV, } \\
\text { laboratory } \\
+\end{array}$ & $\begin{array}{l}\text { prospective, } \\
\text { follow-up }\end{array}$ & $\begin{array}{l}190 \\
\text { discharged }\end{array}$ & 145 & $\begin{array}{l}57 \\
(14)\end{array}$ & $\begin{array}{l}82 \\
(56.6 \%)\end{array}$ & $2,3 \mathrm{mo}$ & good \\
\hline $\begin{array}{l}\text { Gao Y, } \\
2021[56]\end{array}$ & $\begin{array}{l}\text { Guangzhou, } \\
\text { China }\end{array}$ & $\begin{array}{l}\text { 2019- } \\
\text { nCoV,- }\end{array}$ & $\begin{array}{l}\text { prospective } \\
\text { follow-up }\end{array}$ & - & 10 & $\begin{array}{l}50.7 \\
(17.3)\end{array}$ & 7 (70\%) & $1 \mathrm{mo}$ & fair \\
\hline
\end{tabular}

Abbreviations: SARS-CoV, SARS coronavirus; MERS-Cov, MERS coronavirus; 2019-nCoV, 2019 novel coronavirus; ICU, intensive care unit; ARDS, acute respiratory distress syndrome

${ }^{a} \mathrm{~N}_{\text {virus-infected, }}$, number of patients infected with coronavirus; ${ }^{b} \mathrm{~N}_{\mathrm{LFTs}}$, number of patients underwent lung function tests; ${ }^{\mathrm{c}}$ Quality, studies were assessed by the NHLBI's quality assessment tool for observational cohort and cross-sectional studies or the quality assessment tool for Before-After (Pre-Post) studies with no control group; -, not available 
Table 2

Predicted value and damage rate of lung function on average

\begin{tabular}{|c|c|c|c|c|c|c|c|c|c|}
\hline Variables & $\begin{array}{l}\mathbf{N}_{\text {studies }} \\
\text { a }\end{array}$ & ${ }_{b}^{N_{L F T s}, n / N}$ & $\begin{array}{l}\% \text { of pred, rate } \\
(95 \% \mathrm{Cl})\end{array}$ & $1^{2}$ & Egger's & $P_{\text {Virus }}{ }^{c}$ & $\begin{array}{l}P_{\text {Country }} \\
d\end{array}$ & $P_{\text {Setting }}{ }^{e}$ & $P_{\text {Time }} f$ \\
\hline $\begin{array}{l}\text { FVC \% of pred } \\
\mathrm{g}\end{array}$ & 20 & 1309 & $93.8(91.2-96.4)$ & $93.7 \%$ & 0.055 & 0.800 & 0.593 & 0.187 & 0.999 \\
\hline $\begin{array}{l}\mathrm{FVC}<80 \% \text { of } \\
\text { pred }^{\mathrm{h}}\end{array}$ & 14 & $159 / 1331$ & $15.9 \%(9.8-22.0)$ & $93.2 \%$ & 0.011 & 0.979 & 0.106 & 0.372 & 0.904 \\
\hline $\begin{array}{l}\text { FVC mild } \\
\text { damage }^{i}\end{array}$ & 4 & $25 / 30$ & $\begin{array}{l}86.3 \%(74.2- \\
98.3)\end{array}$ & $0.0 \%$ & - & - & - & - & - \\
\hline $\mathrm{FEV}_{1} \%$ of pred & 22 & 1538 & 94.5 (91.7-97.2) & $91.1 \%$ & 0.179 & 0.567 & 0.818 & 0.144 & 0.610 \\
\hline $\begin{array}{l}\mathrm{FEV}_{1}<80 \% \text { of } \\
\text { pred }\end{array}$ & 15 & $155 / 1398$ & $11.6 \%(7.8-15.3)$ & $82.6 \%$ & 0.004 & 0.649 & 0.081 & 0.148 & 0.658 \\
\hline $\begin{array}{l}\mathrm{FEV}_{1} \text { mild } \\
\text { damage }\end{array}$ & 5 & $35 / 39$ & $\begin{array}{l}96.8 \%(73.1- \\
96.8)\end{array}$ & $80.5 \%$ & - & - & - & - & - \\
\hline $\begin{array}{l}\mathrm{FEV}_{1} / \mathrm{FVC} \% \\
\text { of pred }\end{array}$ & 19 & 1010 & $83.3(81.3-85.2)$ & $94.3 \%$ & 0.046 & 0.653 & 0.311 & 0.676 & 0.726 \\
\hline $\begin{array}{l}\mathrm{FEV}_{1} / \mathrm{FVC}< \\
70 \% \text { of pred }\end{array}$ & 12 & $84 / 1104$ & $6.2 \%(3.3-9.1)$ & $79.6 \%$ & 0.022 & 0.135 & 0.065 & 0.082 & 0.126 \\
\hline TLC $\%$ of pred & 15 & 1105 & 94.8 (91.7-97.9) & $91.6 \%$ & 0.463 & 0.193 & 0.535 & 0.551 & 0.857 \\
\hline $\begin{array}{l}\text { TLC }<80 \% \text { of } \\
\text { pred }\end{array}$ & 12 & $266 / 1487$ & $15.6 \%(9.5-21.7)$ & $93.2 \%$ & 0.012 & 0.729 & 0.491 & 0.163 & 0.920 \\
\hline $\begin{array}{l}\text { TLC mild } \\
\text { damage }\end{array}$ & 4 & $36 / 37$ & $99 \%(95-99)$ & $22.5 \%$ & - & - & - & - & - \\
\hline $\mathrm{RV} \%$ of pred & 13 & 906 & $\begin{array}{l}97.2(90.7- \\
103.7)\end{array}$ & $94.3 \%$ & 0.162 & 0.539 & 0.464 & 0.684 & 0.703 \\
\hline $\begin{array}{l}\mathrm{RV}<80 \% \text { of } \\
\text { pred }\end{array}$ & 2 & $97 / 457$ & $17.1 \%(-0.6-34.8)$ & $96.4 \%$ & - & - & - & - & - \\
\hline $\begin{array}{l}\text { DLCO \% of } \\
\text { pred }\end{array}$ & 19 & 1428 & $79.2(76.2-82.2)$ & $92.6 \%$ & 0.241 & 0.293 & 0.645 & 0.050 & 0.895 \\
\hline $\begin{array}{l}\text { DLCO }<80 \% \text { of } \\
\text { pred }\end{array}$ & 21 & $822 / 2435$ & $\begin{array}{l}35.2 \%(28.7- \\
41.8)\end{array}$ & $92.4 \%$ & 0.052 & 0.959 & 0.784 & 0.861 & 0.706 \\
\hline $\begin{array}{l}\text { DLCO mild } \\
\text { damage }\end{array}$ & 7 & $218 / 287$ & $\begin{array}{l}82.9 \%(72.0- \\
93.9)\end{array}$ & $85.1 \%$ & - & - & - & - & - \\
\hline Kco \% of pred & 11 & 763 & $90.2(85.4-95.0)$ & $94.2 \%$ & 0.370 & 0.209 & 0.698 & 0.403 & 0.183 \\
\hline $\begin{array}{l}\text { Kco }<80 \% \text { of } \\
\text { pred }\end{array}$ & 4 & $64 / 298$ & $21.5 \%(1.3-41.6)$ & $95.6 \%$ & - & - & - & - & - \\
\hline $\begin{array}{l}\text { Kco mild } \\
\text { damage }\end{array}$ & 1 & $2 / 2$ & $100.0 \%$ & - & - & - & - & - & - \\
\hline
\end{tabular}

Abbreviations: $\mathrm{Cl}$, confidence intervals; $\mathrm{FVC}$, forced vital capacity; $\mathrm{FEV}_{1}$, forced expiratory volume in 1 second. $F E V_{1} / F V C$, forced vital capacity/forced expiratory volume in 1 second; TLC, total lung capacity; RV, residual volume; DLCO, diffusing capacity of the lung for carbon monoxide; Kco, diffusion capacity for carbon monoxide per liter of alveolar volume 
${ }^{a} \mathrm{~N}_{\text {studies, }}$, number of studies included; ${ }^{b} \mathrm{~N}_{\mathrm{LFTs}}, \mathrm{n} / \mathrm{N}$, number of patients underwent lung function tests, the lung function damage rate or the ratio of mild damage; ${ }^{\mathrm{c}} P_{\text {Virus, }}$ the $P$ value of meta regression in different coronavirus; ${ }^{\mathrm{d}} P_{\text {Country, }}$, the $P$ value of meta regression in different countries; ${ }^{\mathrm{e}} P_{\text {Setting, }}$, the $P$ value of meta regression in different illness settings; ${ }^{f} P_{\text {Time, }}$, the $P$ value of meta regression in different measurement times; ${ }^{g} \mathrm{FVC} \%$ of pred, the predicted value of $\mathrm{FVC}$; ${ }^{\mathrm{h}} \mathrm{FVC}<80 \%$ of pred, damage rate of $\mathrm{FVC}$; i FVC mild damage, the mild damage ratio of FVC (60 $\leq \mathrm{FVC}<80 \%$ of pred); $\mathrm{l}^{2}$, index for the degree of heterogeneity; $P$ value, significant at $P<0.05$ and present in bold; Egger's, index for the degree of publication bias; -, not available

Table 3

Differences of predicted value and damage rate of lung function in severe/critical vs. non-severe/critical

\begin{tabular}{|c|c|c|c|c|c|c|c|}
\hline Variables & $\begin{array}{l}\mathrm{N}_{\text {studies }} \\
\text { a }\end{array}$ & $\begin{array}{l}N_{\text {severe/critical, }} \\
n / N_{\text {severe/critical }} b^{b}\end{array}$ & $\begin{array}{l}N_{\text {non-severe/critical, }} \\
n / N_{\text {non-severe/critical }}\end{array}$ & $\begin{array}{l}\text { WMD, } \\
\text { RR }\end{array}$ & $95 \% \mathrm{Cl}$ & $1^{2}$ & $P$ \\
\hline FVC $\%$ of pred ${ }^{d}$ & 9 & 237 & 453 & -6.21 & $\begin{array}{l}-8.76- \\
-3.66\end{array}$ & $24.5 \%$ & 0.000 \\
\hline $\begin{array}{l}\text { FVC }<80 \% \text { of } \\
\text { pred }^{\text {e }}\end{array}$ & 6 & $29 / 357$ & $28 / 361$ & 1.48 & $\begin{array}{l}0.88- \\
2.47\end{array}$ & $0.0 \%$ & 0.138 \\
\hline $\mathrm{FEV}_{1} \%$ of pred & 10 & 283 & 531 & -3.50 & $\begin{array}{l}-5.86- \\
-1.14\end{array}$ & $0.0 \%$ & 0.004 \\
\hline $\begin{array}{l}\mathrm{FEV}_{1}<80 \% \text { of } \\
\text { pred }\end{array}$ & 7 & $31 / 402$ & $42 / 437$ & 1.07 & $\begin{array}{l}0.66- \\
1.74\end{array}$ & $0.0 \%$ & 0.776 \\
\hline $\begin{array}{l}\mathrm{FEV}_{1} / \mathrm{FVC} \% \text { of } \\
\text { pred }\end{array}$ & 7 & 133 & 359 & 0.57 & $\begin{array}{l}-1.47- \\
2.61\end{array}$ & $55.8 \%$ & 0.585 \\
\hline $\begin{array}{l}\mathrm{FEV}_{1} / \mathrm{FVC}<70 \% \\
\text { of pred }\end{array}$ & 5 & $38 / 398$ & $21 / 261$ & 0.99 & $\begin{array}{l}0.58- \\
1.69\end{array}$ & $0.0 \%$ & 0.968 \\
\hline TLC $\%$ of pred & 8 & 262 & 431 & -7.97 & $\begin{array}{l}-10.52- \\
-5.43\end{array}$ & $7.3 \%$ & 0.000 \\
\hline $\begin{array}{l}\text { TLC }<80 \% \text { of } \\
\text { pred }\end{array}$ & 6 & $91 / 445$ & $43 / 355$ & 2.00 & $\begin{array}{l}1.38- \\
2.90\end{array}$ & $0.0 \%$ & 0.000 \\
\hline $\mathrm{RV} \%$ of pred & 5 & 153 & 316 & -10.43 & $\begin{array}{l}-15.86- \\
-5.01\end{array}$ & $0.0 \%$ & 0.000 \\
\hline $\mathrm{RV}<80 \%$ of pred & 2 & $74 / 288$ & $22 / 156$ & 1.40 & $\begin{array}{l}0.89- \\
2.20\end{array}$ & $0.0 \%$ & 0.146 \\
\hline DLCO \% of pred & 9 & 277 & 519 & -11.60 & $\begin{array}{l}-14.23- \\
-8.98\end{array}$ & $29.0 \%$ & 0.000 \\
\hline $\begin{array}{l}\text { DLCO }<80 \% \text { of } \\
\text { pred }\end{array}$ & 8 & $237 / 477$ & $146 / 480$ & 1.74 & $\begin{array}{l}1.46- \\
2.07\end{array}$ & $6.4 \%$ & 0.000 \\
\hline Kco \% of pred & 5 & 179 & 260 & -5.97 & $\begin{array}{l}-9.22- \\
-2.72\end{array}$ & $0.0 \%$ & 0.000 \\
\hline $\begin{array}{l}\text { Kco }<80 \% \text { of } \\
\text { pred }\end{array}$ & 2 & $25 / 59$ & $35 / 132$ & 1.44 & $\begin{array}{l}0.95- \\
2.20\end{array}$ & $0.0 \%$ & 0.088 \\
\hline
\end{tabular}

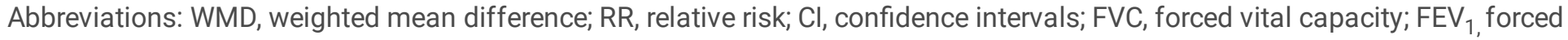
expiratory volume in 1 second. $F V_{1} / F V C$, forced vital capacity/forced expiratory volume in 1 second; TLC, total lung capacity; $\mathrm{RV}$, residual volume; DLCO, diffusing capacity of the lung for carbon monoxide; Kco, diffusion capacity for carbon monoxide per liter of alveolar volume

${ }^{a} N_{\text {studies, }}$, number of studies included; ${ }^{b} N_{\text {severe/critical, }} \mathrm{n} / \mathrm{N}_{\text {severe/critical, }}$ number of severe/critical patients, the damage rate of lung function in severe/critical; ${ }^{c} N_{\text {non-severe/critical, }} \mathrm{n} / \mathrm{N}_{\text {non-severe/critical, }}$ number of non-severe/critical patients, the damage rate of lung 
function in non-severe/critical; ${ }^{\mathrm{d}} \mathrm{FVC} \%$ of pred, the predicted value of FVC; ${ }^{\mathrm{e}} \mathrm{FVC}<80 \%$ of pred, damage rate of FVC; $\mathrm{I}^{2}$, index for the degree of heterogeneity; $P$ value, significant at $P<0.05$ and present in bold

Table 4

Changes of predicted value and damage rate of lung function within one-year follow-up

\begin{tabular}{|c|c|c|c|c|c|c|c|}
\hline Variables & $\begin{array}{l}\mathbf{N}_{\text {studies }} \\
\text { a }\end{array}$ & $\mathrm{n}_{\mathrm{first}} \mathrm{b}$ & $\mathrm{n}_{\text {last }}{ }^{\mathrm{c}}$ & $\begin{array}{l}\text { WMD, } \\
\text { OR }\end{array}$ & $95 \% \mathrm{Cl}$ & $1^{2}$ & $\mathbf{P}$ \\
\hline $\begin{array}{l}\text { FVC \% of pred } \\
\text { d }\end{array}$ & 5 & 223 & 243 & -5.95 & $-10.52-1.38$ & $54.2 \%$ & 0.011 \\
\hline $\begin{array}{l}\mathrm{FVC}<80 \% \text { of } \\
\text { pred }^{\text {e }}\end{array}$ & 3 & $53 / 236$ & $45 / 242$ & 1.38 & $0.83-2.31$ & $0.0 \%$ & 0.219 \\
\hline $\begin{array}{l}\mathrm{FEV}_{1} \% \text { of } \\
\text { pred }\end{array}$ & 5 & 223 & 243 & -5.27 & $-11.05-0.52$ & $67.2 \%$ & 0.074 \\
\hline $\begin{array}{l}\mathrm{FEV}_{1}<80 \% \text { of } \\
\text { pred }\end{array}$ & 3 & $43 / 237$ & $45 / 246$ & 1.00 & $0.59-1.69$ & $0.0 \%$ & 0.998 \\
\hline $\begin{array}{l}\mathrm{FEV}_{1} / \mathrm{FVC} \% \\
\text { of pred }\end{array}$ & 3 & 43 & 43 & 2.77 & $0.01-5.53$ & $30.4 \%$ & 0.049 \\
\hline TLC \% of pred & 3 & 192 & 212 & -6.79 & $-15.54-1.95$ & $88.3 \%$ & 0.128 \\
\hline $\begin{array}{l}\text { TLC }<80 \% \text { of } \\
\text { pred }\end{array}$ & 2 & $21 / 224$ & $20 / 233$ & 1.11 & $0.59-2.12$ & $0.0 \%$ & 0.743 \\
\hline RV $\%$ of pred & 3 & 192 & 212 & -7.25 & $-16.90-2.40$ & $76.7 \%$ & 0.141 \\
\hline $\begin{array}{l}\text { DLCO \% of } \\
\text { pred }\end{array}$ & 3 & 192 & 212 & -4.43 & $-14.52-5.67$ & $92.6 \%$ & 0.390 \\
\hline $\begin{array}{l}\text { DLCO }<80 \% \text { of } \\
\text { pred }\end{array}$ & 2 & $21 / 224$ & $20 / 233$ & 1.07 & $0.69-1.66$ & $84.6 \%$ & 0.754 \\
\hline Kco \% of pred & 2 & 109 & 109 & -7.76 & $-11.58-3.93$ & $31.4 \%$ & 0.000 \\
\hline $\begin{array}{l}\text { Kco }<80 \% \text { of } \\
\text { pred }\end{array}$ & 1 & $2 / 97$ & $0 / 97$ & 5.11 & $0.24-107.73$ & - & 0.295 \\
\hline
\end{tabular}

Abbreviations: WMD, weighted mean difference; OR, odds ratio; $\mathrm{Cl}$, confidence intervals; $\mathrm{FVC}$, forced vital capacity; $\mathrm{FEV}_{1}$, forced expiratory volume in 1 second. $F E V_{1} / F V C$, forced vital capacity/forced expiratory volume in 1 second; TLC, total lung capacity; $\mathrm{RV}$, residual volume; DLCO, diffusing capacity of the lung for carbon monoxide; Kco, diffusion capacity for carbon monoxide per liter of alveolar volume

${ }^{a} \mathrm{~N}_{\text {studies, }}$ number of studies included; ${ }^{b} n_{\text {first }}$, number of patients underwent lung function tests at the first measurement time; ${ }^{c}$ $\mathrm{n}_{\text {last }}$, number of patients underwent lung function tests at the last measurement time; ${ }^{d} \mathrm{FVC} \%$ of pred, the predicted value of FVC; ${ }^{\text {e }}$ FVC $<80 \%$ of pred, damage rate of FVC; $I^{2}$, index for the degree of heterogeneity; $P$ value, significant at $P<0.05$ and present in bold; --, not available

\section{Figures}


7798 articles identified through databases searching:

PubMed: 3631, Cochrane: 265, Embase: 894, Web of science: 3008

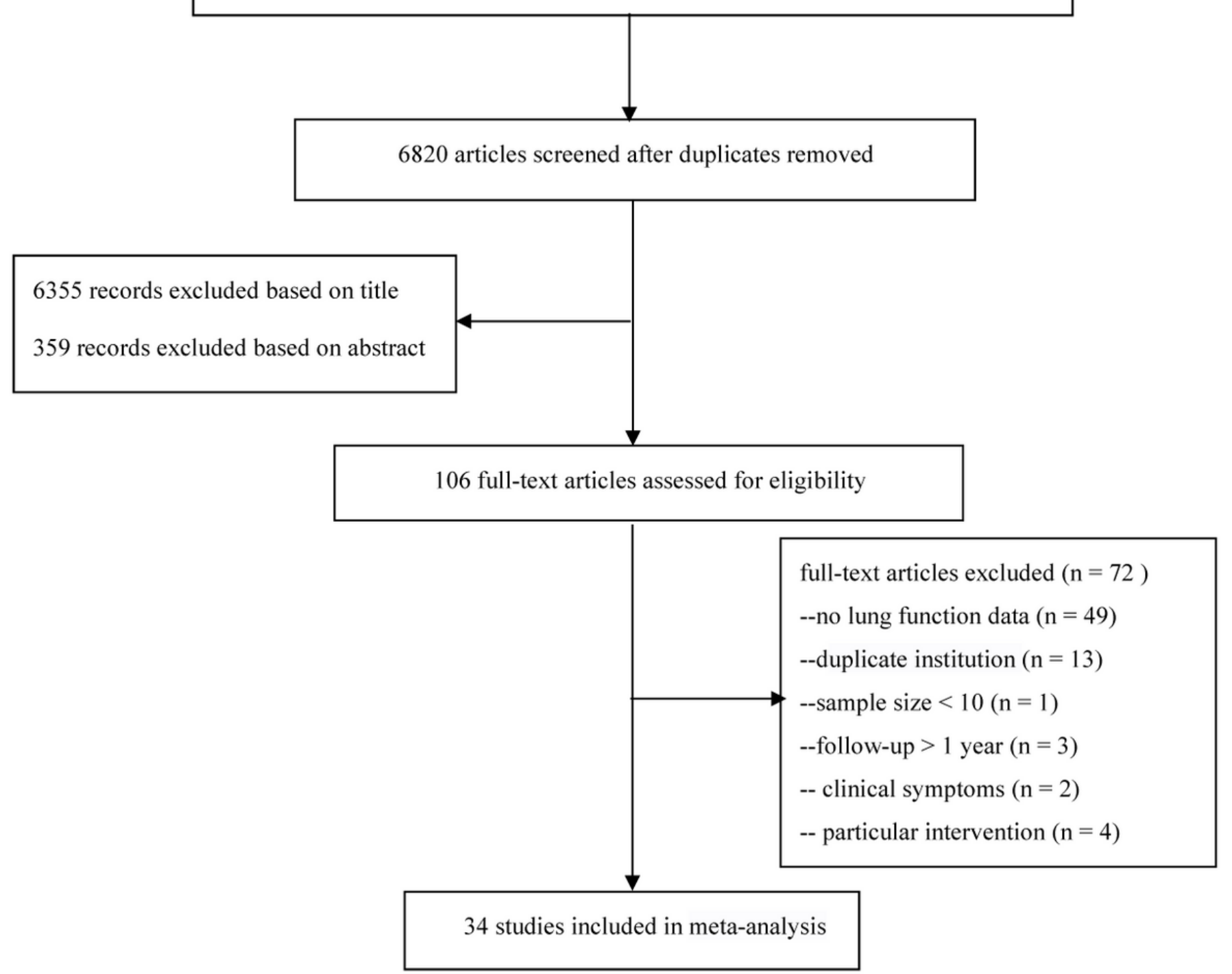

Figure 1

Flow chart of article selection. 


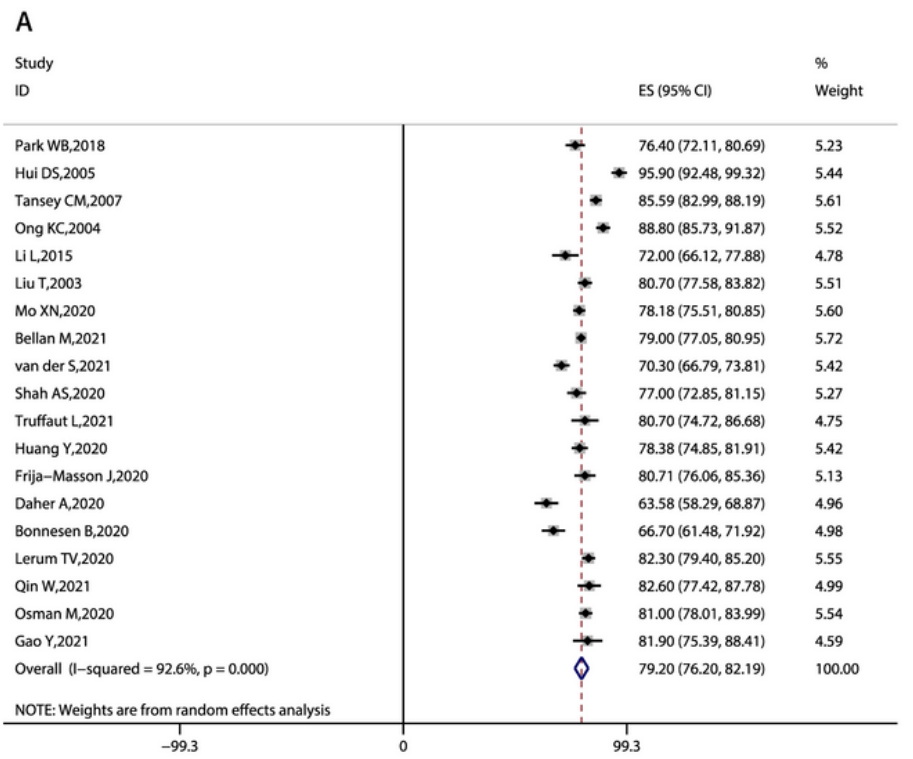

\section{B}

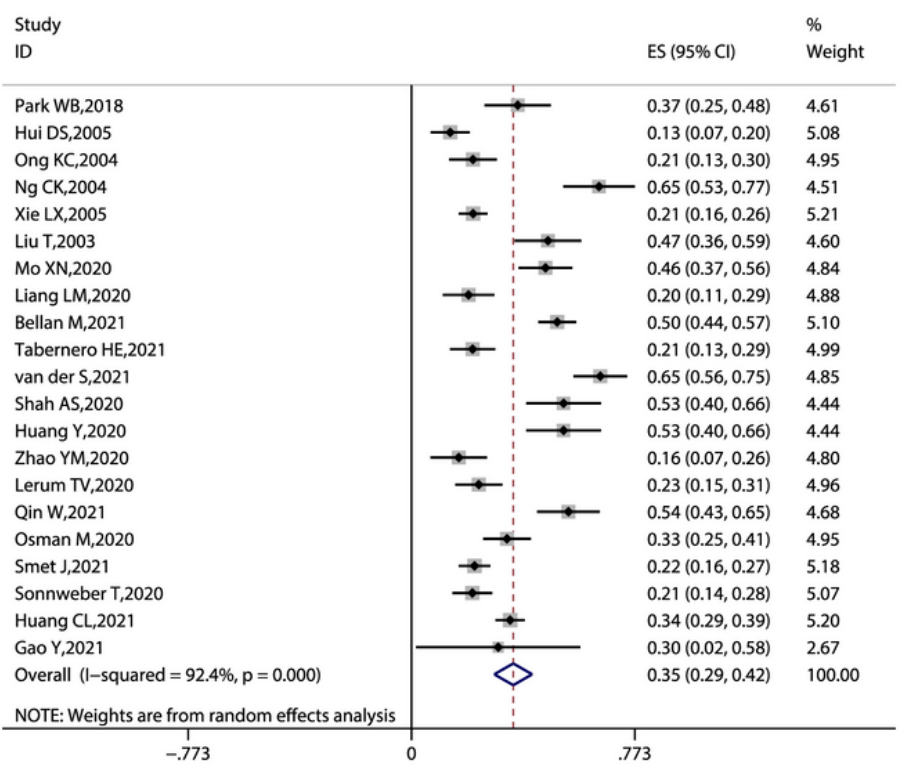

\section{Figure 2}

Meta-analysis of DLCO on average. A, predicted value of DLCO; B, damage rate of DLCO. Abbreviations: DLCO, diffusing capacity of the lung for carbon monoxide. 

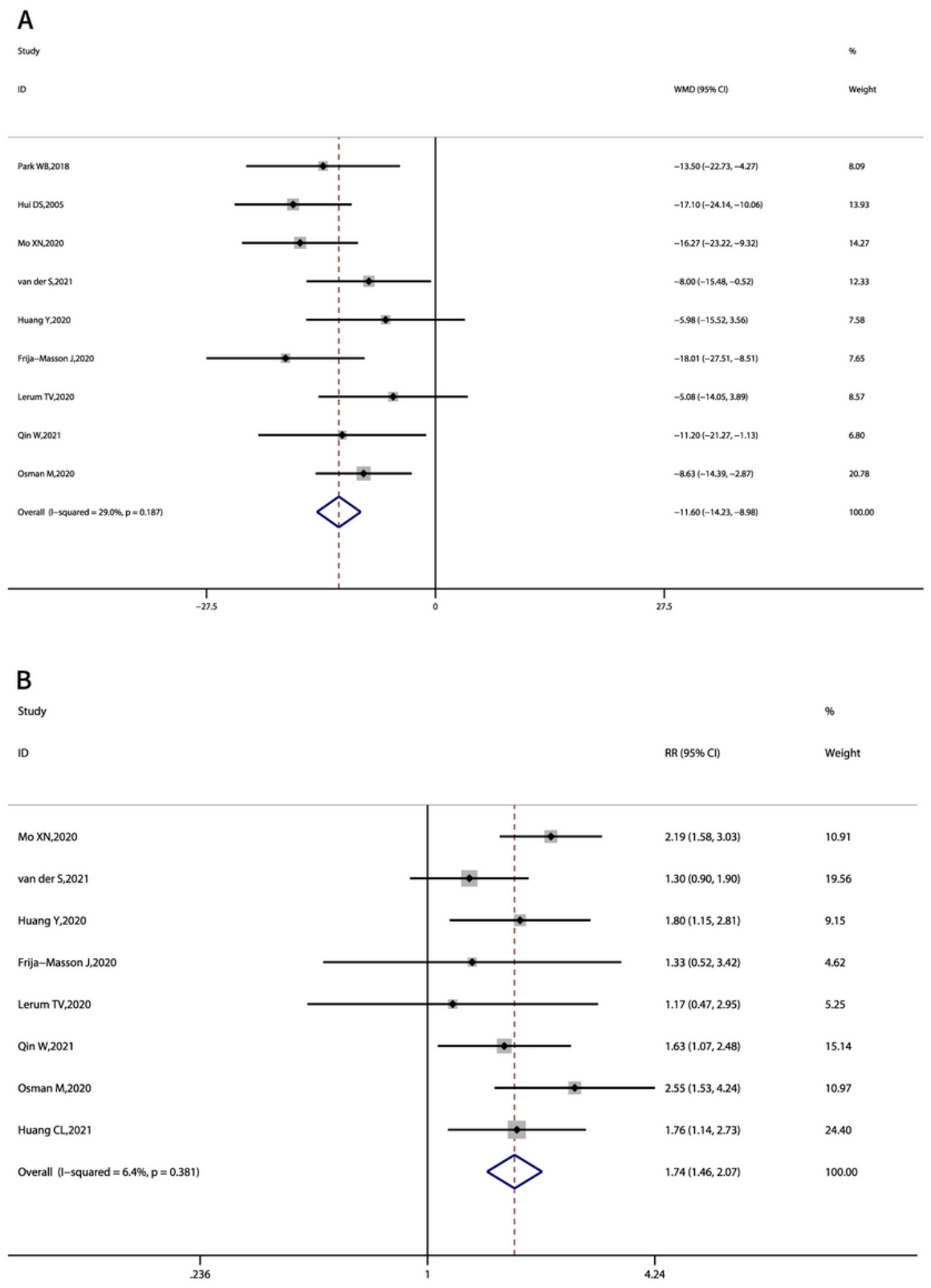

\section{Figure 3}

Meta-analysis of DLCO in severe/critical vs. non-severe/critical. A, predicted value of DLCO; B, damage rate of DLCO. Abbreviations: DLCO, diffusing capacity of the lung for carbon monoxide.

\section{Supplementary Files}

This is a list of supplementary files associated with this preprint. Click to download.

- SupplementaryFigure1.tif 